\title{
Research of Model Scale Seawater Intrusion using Geoelectric Method
}

\author{
Supriyadi, Agus Yulianto, and Andi Haryanto ${ }^{1}$
}

\begin{abstract}
A depth experience and knowledge are needed in analyzing the prediction of seawater intrusion. We report here a physical modelling for monitoring the model scale of seawater intrusion. The model used in this research is glass basin consists of two parts; soil and seawater. The intrusion of seawater into soil in the glass basin is modelled. The results of 2-D inversion by using software Res2DInv32 showed that the monitoring of seawater intrusion, in soil model scale, can be detected by using Schlumberger configuration resistivity method. The watering process of freshwater into soil caused the electric resistivity value decreased. This phenomenon can be seen from the transition of the resistivity pseudo section before and after the watering process using different cummulative volume of freshwater in different soil. After being intruded by the seawater, the measured soil resistivity is $2.22 \Omega \mathrm{m}-5.69 \Omega \mathrm{m}$ which means that the soil had been intruded.
\end{abstract}

Keywords-geoelectrical method, seawater intrusion

Abstrak-Pendugaan intrusi air laut di lapangan memerlukan pengalaman dan pengetahuan dalam menganalisis, sehingga dalam penelitian ini dilakukan suatu pemodelan fisik untuk monitoring intrusi air laut skala model. Model yang digunakan adalah bak kaca yang memiliki dua bagian, bagian pertama berisi medium tanah dan bagian kedua berisi air laut. Pada bak kaca tersebut dimodelkan intrusi air laut ke dalam tanah. Hasil inversi 2-D menggunakan software Res2DInv32 menunjukkan bahwa monitoring intrusi air laut dalam medium tanah skala model dapat dideteksi menggunakan metode resistivitas konfigurasi Schlumberger. Penyiraman air tawar ke dalam tanah menyebabkan nilai resistivitas listrik tanah menurun. Hal ini dapat dilihat dari perubahan penampang isoresisivitas sebelum dan sesudah penyiraman air dengan volume kumulatif air tawar dalam tanah yang berbeda. Saat diintrusikan air laut, resistivitas tanah yang terukur adalah $2,22 \Omega m-5,69 \Omega m$ yang berarti bahwa lapisan tanah telah mengalami intrusi.

Kata Kunci-metode geolistrik, intrusi air laut

\section{INTRODUCTION}

$\mathrm{G}$ roundwater is a renewable natural resource that has important role towards living. The higher the population growth, the higher the exploitation of groundwater. The high number of groundwater exploitation caused the imbalance condition between the exploitation and the groundwater formation. This condition can decrease the groundwater surface level [1]. In coastal areas, the decreasing of groundwater surface level will cause intrusion of seawater to the land because groundwater pressure is lower than seawater pressure.

As a result, in dry season an area suffers from drought and in rainy season it suffers from flood. A problem which may occur in this condition is whether the stored water is still in the reservoir we want or have been moved to another place. The migration of seawater is a problem which interferes with the provision of drinking water supplies [2].

The seawater intrusion causes a huge damage in environment, health and economics. Therefore, the monitoring of seawater intrusion is needed in order to decrease the negative impacts of seawater intrusion for example water quality and corrosion in the building foundation.

On the other hand, in measuring and acquisitioning field data, experience and knowledge about the accurate configuration in analyzing the appearance of geological condition in the field is needed. The physical and mathematical modelling are done a lot for making the understanding of geological matter easier to do. It is done by making a model from the system in nature.

Supriyadi, Agus Yulianto, and Andi Haryanto are with Department of Physics, Universitas Negeri Semarang, Semarang, 50229, Indonesia. E-mail: pryfis@yahoo.com
Based on Law and Kelton, a model makes the predict and analysis of a problem in the field become easier [3].

In the previous research done by Juandi [4], it has been showed that geoelectrical method can be used for determining groundwater pollution. He succeeded in analyzing oil palm waste by applying geoelectrical method. Moreover, Ngadimin and Handayani [5] also performed a monitoring research on the seepage of physical modelling waste in laboratory. They had succeeded in predicting the spread of liquid contaminant in the soil which was associated with conductive fluid which showed the accumulation of seepage waste groundwater pollution enabling the rise of.

In addition, the geoelectrical method has been proven as the best method in detecting the groundwater quality and also as a method which is suitable for shallow exploration. Therefore, this method is extensively used in geophysics exploration such as determining the depth of basement rock, searching of groundwater aquifer, the geothermal exploration, etc. [6].

Most rocks are poor conductors and hence have very high resistivity. Commonly, rocks are porous with fluid (especially water) filling them. The characteristics of electrical conductivity of rock, are strongly influenced by water amount, salinity, and distribution in the rocks. Those rocks become electrical conductor where the conduction of electric current is carried by the electrolytic ions in the water.

The simplest approach, in the study of electricity indication in the earth, is by regarding the Earth as an isotropic homogenous medium. With this treatment, the electric field from point sources in the earth is considered to have spherical symmetry (Figure 1). The value of electric resistivity of a formation under surface can be determined by using Equation 1 . 
$V=\frac{i \rho}{4 \pi r}$

Where $V$ is the potential difference, $r$ is the radius of isotropic homogenous medium, $i$ is the electric current, $\rho$ is resistivity of rock, and $\pi=3.14$.

The Earth's surface which electrified (Figure 2) is a half spherical area, so the Equation 1 becomes,

$V=\frac{i \rho}{2 \pi r}$ or $\rho=2 \pi r \frac{V}{i}$

Figure 3 shows the diagrammatical design of the measurement of potential difference between point $M$ and $\mathrm{N}$ from electric current source $\mathrm{A}$ and $\mathrm{B}$ on the surface. The difference is computed by

$$
\begin{aligned}
\Delta V & =V_{M}-V_{N} \\
& =\frac{i \rho}{2 \pi}\left[\left(\frac{1}{A M}-\frac{1}{B M}\right)-\left(\frac{1}{A N}-\frac{1}{B N}\right)\right]
\end{aligned}
$$

So that,

$$
\begin{aligned}
\rho & =2 \pi\left[\left(\frac{1}{A M}-\frac{1}{B M}\right)-\left(\frac{1}{A N}-\frac{1}{B N}\right)\right]^{-1} \frac{\Delta V}{i} \\
& =K \frac{\Delta V}{i}
\end{aligned}
$$

where $\mathrm{K}$ is the correcting position factor of potential electrode and current electrode. A, B, M, and $\mathrm{N}$ are the electrodes position.

The electrode line sketch used in this research is drawn in Figure 4 and the resistivity values of some materials are shown in the Table 1.

The seawater intrusion is a phenomenon which happens a lot in coast aquifer. Generally, this phenomenon happens when the groundwater surface on freshwater aquifer is lower than the average sea surface causing seawater push the fresh water to land. If the groundwater surface is higher than the average sea surface, the freshwater will push it to the sea [9]. In analysing sea water intrusion in current place, it is better for the researchers to have a depth study about sea water measurement by conducting an early analysis in lab by using model scale. This model scale method is expected to give the researcher an experience on how to conduct sea water intrusion measurement and it is expected also could give the same result as field measurement.

\section{METHOD}

The instrument used in this study is a set of resistivity meter with electrodes. The research material was a glass vessel with a length of $150 \mathrm{~cm}$, width $104 \mathrm{~cm}, 45 \mathrm{~cm}$ high, and filled with clay and seawater which was arranged as in the Figure 5.

The scale between the model and the condition in the field was $1 \mathrm{~cm}: 5 \mathrm{~m}$. The geoelectric was activated, measuring the electric current and the potential difference at the dry soil early condition before being intruded by the seawater (settled up by covering the inlet of the seawater into the soil and covering the hole out of the freshwater).

The soil then being watered using freshwater with the cumulative volume of water in the soil is 150 liters, 300 liters, and so on. It was done continuously until the saturated water can not absorb the freshwater. Each dose of water which was sprinkled was measured using geoelectric method. Once, the water in the saturated state, 100 liters of fresh water was removed by opening the fresh water vessel.

To intrude the soil to saturation condition, the inlet of the seawater into the soil was opened. When the procedure is completed, the electrical current and potential difference in the soil, which had been intruded by the seawater, can be measured. The measured data were then analyzed and interpreted using software Res2dinv [10].

\section{RESULT AND DISCUSSION}

1. The land's resistivity pseudo section before being watered by the freshwater

The large porosity of the dry soil had caused the contact electrode injected into the medium could not flow properly. This was causing the resistivity meter GSound Portable could not work properly. The electrical current could not pass through the air cavities that filled the spaces between soil particle interfaces. Therefore, the wet soil medium was given over the dry soil medium in order to give a better electrode contacts so that the current was able to flow to the bottom of the dry soil medium.

Data processing that resistivity section inverse model of soil early before the fresh water watering is as shown in Figure 6 (Appendix). Soil resistivity measurement results were obtained by using geoelectric obtained value of the soil $\rho$ was about $79.4 \Omega \mathrm{m}-93.87 \Omega \mathrm{m}$ with $18 \%$ iteration error.

The theoretical value of $\rho$ soil in Table 1 was $1 \Omega \mathrm{m}$ $104 \Omega \mathrm{m}$, so that $\rho$ soil values measured were in the theoretical value range. Based on the results of this modelling, it can be concluded that the geoelectric can work in the model and in the soil medium used. The interpretation of geoelectric measurement's result was performed by looking at the results of pseudo section resistivity from data computation result. The resistivity's value range in pseudo section can bee seen in the right column and the materials is in the left.

2. The resistivity pseudo section of the soil with cummulative volume of the freshwater in the soil 150 liters.

Figure 7 (Appendix) showed the cross-sectional resistivity of the soil after being watered using 150 liters freshwater. The value of the soil resistivity measured was about $54.55 \Omega \mathrm{m}-78.08 \Omega \mathrm{m}$ with $19.6 \%$ iteration error. It showed that the soil resistivity value had decreased from its initial.

3. The resistivity pseudo section of soil with cummulative volume of freshwater in the soil 300 liters

Figure 8 (Appendix) showed the cross-sectional resistivity of soil by using 300 liters freshwater in the soil. The soil resistivity value after the second freshwater watering was about $31.6 \Omega \mathrm{m}-37.8 \Omega \mathrm{m}$ with $12.5 \%$ iteration error. It could be seen that the soil resistivity had lower value than the initial watering process in ' $b$ '.

4. The esistivity pseudo section of soil with the cummulative volume of freshwater in the soil is 427.5 liters.

The Figure 9 (Appendix) showed that the resistivity pseudo section of the soil had increased freshwater from 300 to 427.5 liters after being treated with the third watering using the cummulative volume of freshwater in 
the soil. This third freshwater watering was done until the soil was saturated and could not absorb the freshwater anymore because the spaces between soil grains were filled with the freshwater. Figure 10 (Appendix) showed the value of soil resistivity in a saturated state was about $13.4 \Omega \mathrm{m}-15.25 \Omega \mathrm{m}$ with $8.4 \%$ iteration error. It means that soil resistivity value had decreased from the resistivity value on the first and second watering.

From Figure 6 to 9 (Appendix) it can be concluded that the watering process in the soil affects the decreasing of the soil resistivity value. The watering process by using freshwater on the dried soil, which made it became saturated, caused the resistivity value decreased. The more cummulative volume of the freshwater in the soil, the resistivity value would decrease further. This decreasing occurred because water is conductive and always filled the interface space of soil that previously filled with air. The research performed [2] for modeling application of Schlumberger geoelectric configuration method to investigate the groundwater existence indicated that the modeling can be used for that purpose with indicator obtained from water resistivity range between $0.5 \Omega \mathrm{m}-100 \Omega \mathrm{m}$ the same as listed in the Table 1 . This proves that the soil is electrolytic where the conduction of electric current carried by the electrolytic ions in the water. The soil resistivity values after watering were shown in the Table 2 .

5. Soil resistivity pseudo section that intruded by seawater

In Figure 10 (Appendix) the moves of seawater seepage is tent from the centre-right side to the bottom left. This tendency happened as the effect of the soil density different caused by the location of the water inlet which is located in the bottom left and right centre of the constrictor glass (Figure 5), so that the seawater filled all the spaces around the water discharge hole.

The soil resistivity of the seawater intrusion was approximately $2.22 \Omega \mathrm{m}-5.69 \Omega \mathrm{m}$. This resistivity value was different from that in Table 1 . The resistivity value in the Table 1 is the resistivity value of pure seawater whereas in this study the measured resistivity value is the value of resistivity of brackish water. This is because the seawater mixed with fresh water in the soil. The difference resistivity value obtained from the measurement process, with it's value in the Table 1, was caused by the electrodes arrangement. As explained by [2] which stated that big change of resistivity pattern occurred when the measurement electrodes arrangement was near the water injection spot. In the contrary, the small change of resistivity pattern occured when the measurement electrodes arrangement was further away from the water injection spot. This reinforces the conclusion that the water existence affects the material resistivity.

\section{CONCLUSION}

Based on lab-scale measurement, the soil resistivity value before the watering is equal to $79.4 \Omega \mathrm{m}-93.87$ $\Omega \mathrm{m}$. The watering by using freshwater into the soil cause the soil resistivity value decreases. The resistivity soil values after the watering respectively are $54.55 \Omega \mathrm{m}-$ $78.08 \Omega \mathrm{m}$ for the volume of 150 liters of freshwater in the soil; $31.6 \Omega \mathrm{m}-78.08 \Omega \mathrm{m}$ for volume of 300 liters of freshwater in the soil, and from $13.4 \Omega \mathrm{m}-15,25 \Omega \mathrm{m}$ for volume of 427.5 liters of freshwater in the soil (soil in a state of saturation). Last, the soil resistivity that intruded by the seawater is $2.22 \Omega \mathrm{m}-5.69 \Omega \mathrm{m}$.

The results showed that the geoelectric Schlumberger configuration model can be used as substitute medium in the seawater intrusion measurement. The result of the study had proved that this method can measure the seawater intrusion as well as the directly measurement in the field. The research result performed by [11] about the mapping of sea water intrusion distribution by using geoelectric method showed that the soil intruded by sea water had variations resistivity type which tent to experienced a big difference where the lowest value which spread laterally centered, in the middle of this, suspected as the central of sea water in the soil with the value of resitivity distribution patterns ranging 0.0178 $\Omega \mathrm{m}-14.0 \Omega \mathrm{m}$. This result was difference from the measurement results because the soil layer used for modelling could not exactly the same as the soil layer in the field.

This model scale also can help a researcher to have an initial measurement before they go to the research field and make it easier to do. So that, without directly going to the field, the researchers are able to analyze the seawater intrusion by using the same kind of soil in the field.

\section{ACKNOWLEDGMENT}

Thanks to the Directorate General of Higher Education, Ministry of National Education, Republic of Indonesia in accordance with the letter of agreement implementation research grant number of Hibah Bersaing 036/SP2H/PP/DP2M/III/2010 dated March 1, 2010. 


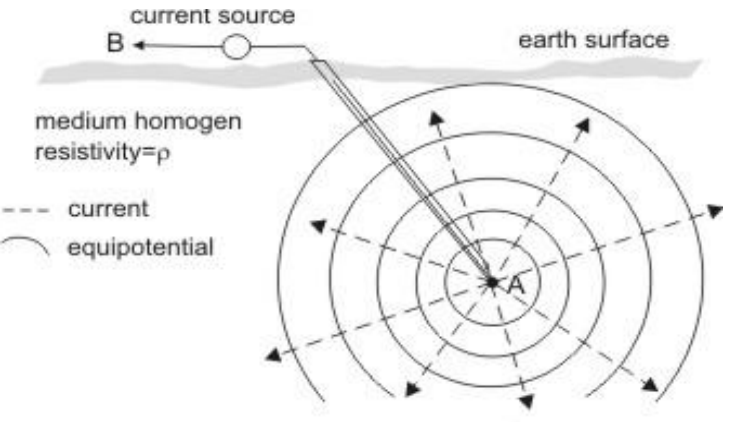

Figure 1. The current point $\mathrm{A}$ in isotropic homogenous medium, current source B is considered to be at the point of infinity

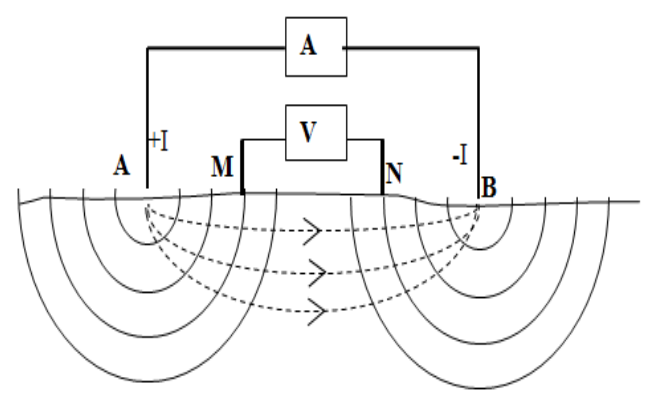

Figure 3. The current flow's pattern and equipotential field between two current electrodes with opposite polarity

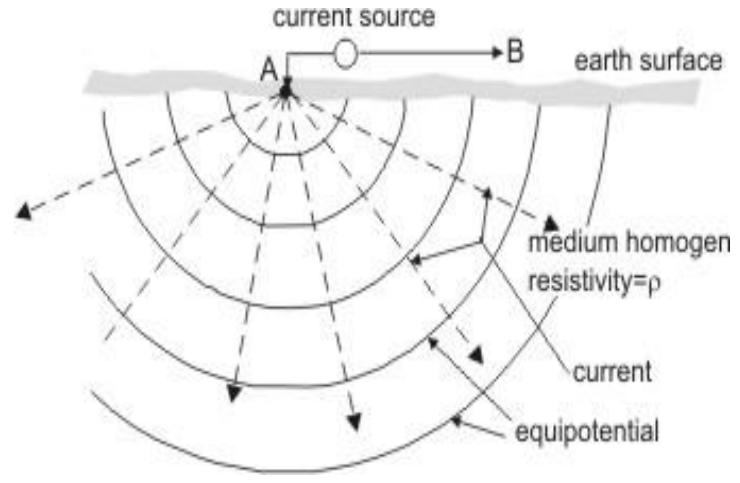

Figure 2. The source of single current A in homogenous half space medium. Current B is considered to be at the point of infinity

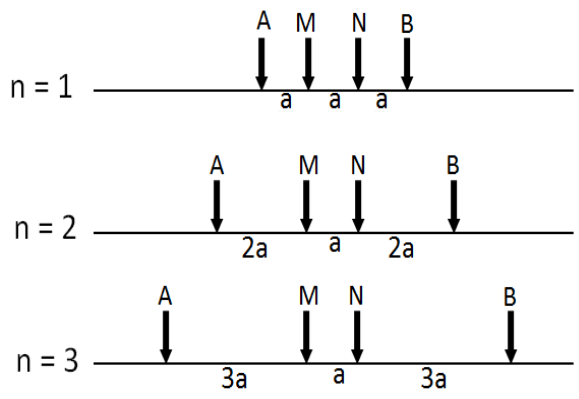

Figure 4. The electrode line sketch for Schlumberger configuration [7]

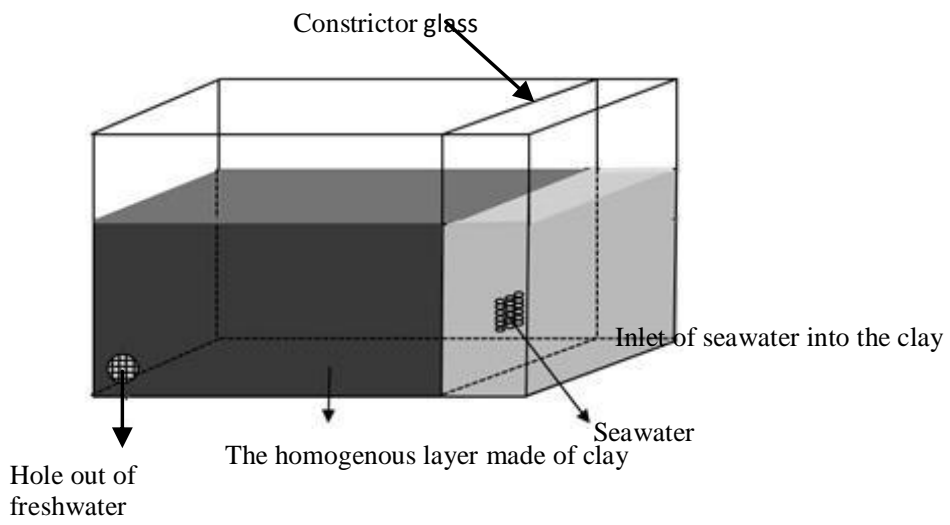

Figure 5. The physical model of seawater intrusion on the scale model

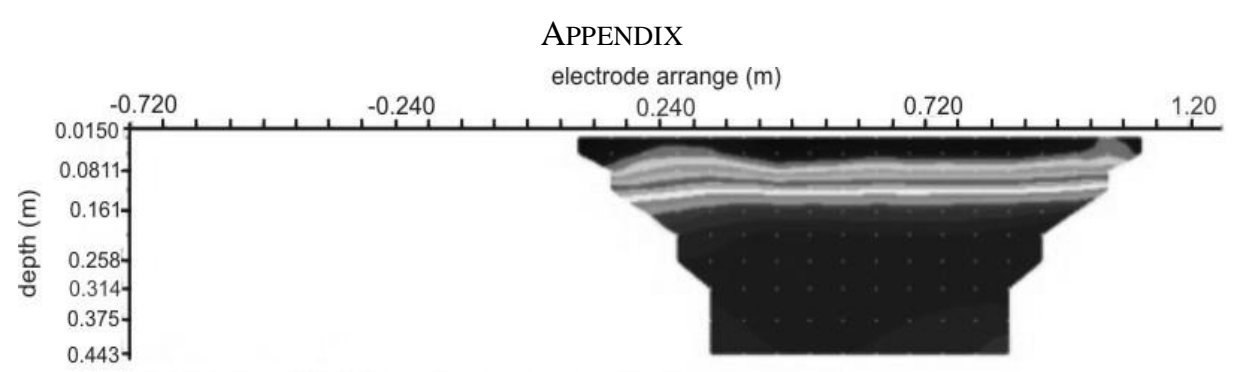

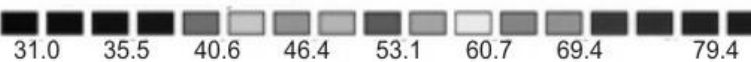

resistivity $(\Omega \mathrm{m})$

Figure 6 . The resistivity pseudo section of the soil before watering freshwater 


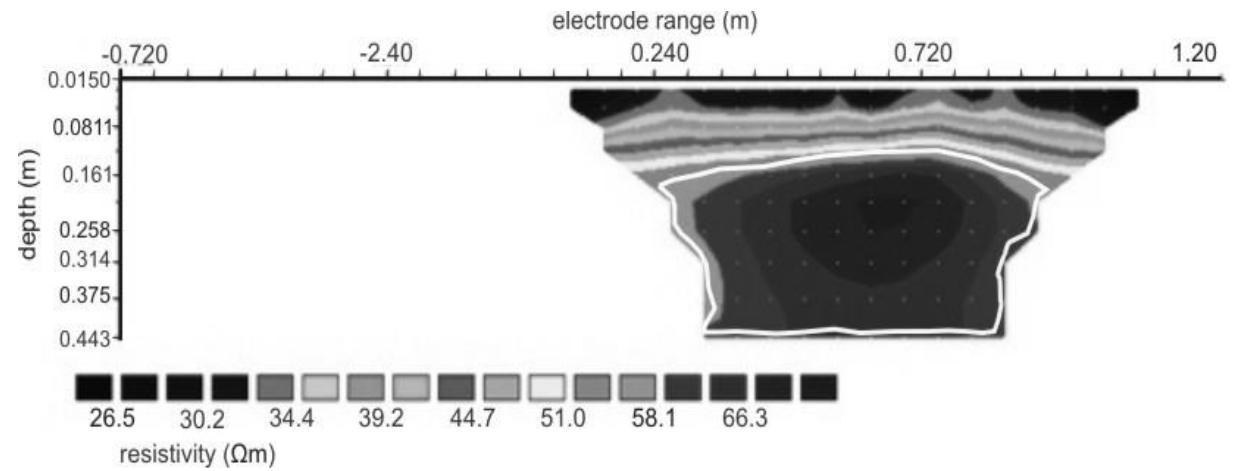

Figure 7. The resistivity pseudo section of the soil with cummulative volume of freshwater in the soil of 150 liters
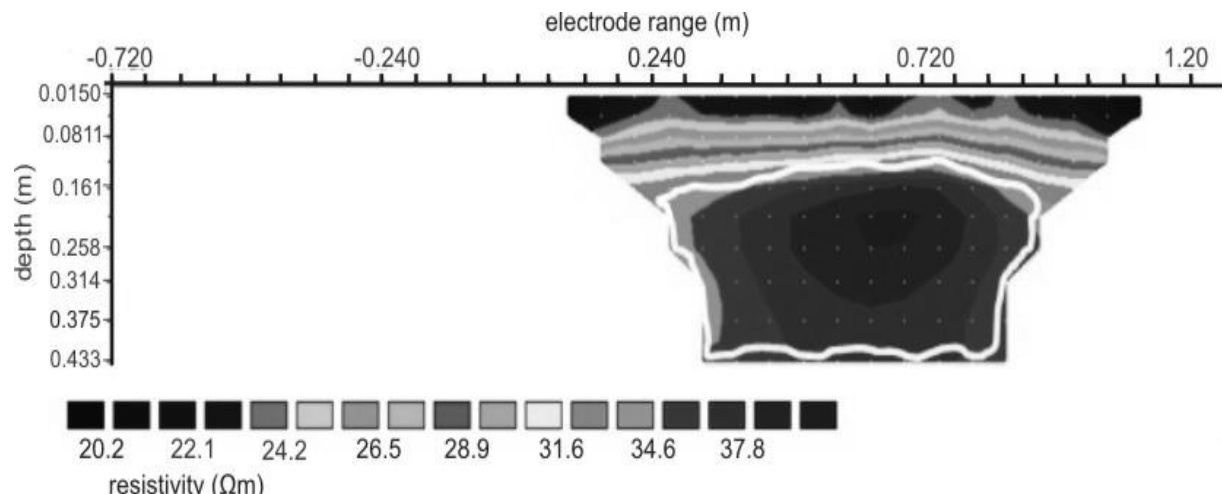

Figure 8 . The resistivity pseudo section of the soil with cummulative volume of freshwater in the soil of 300 liters

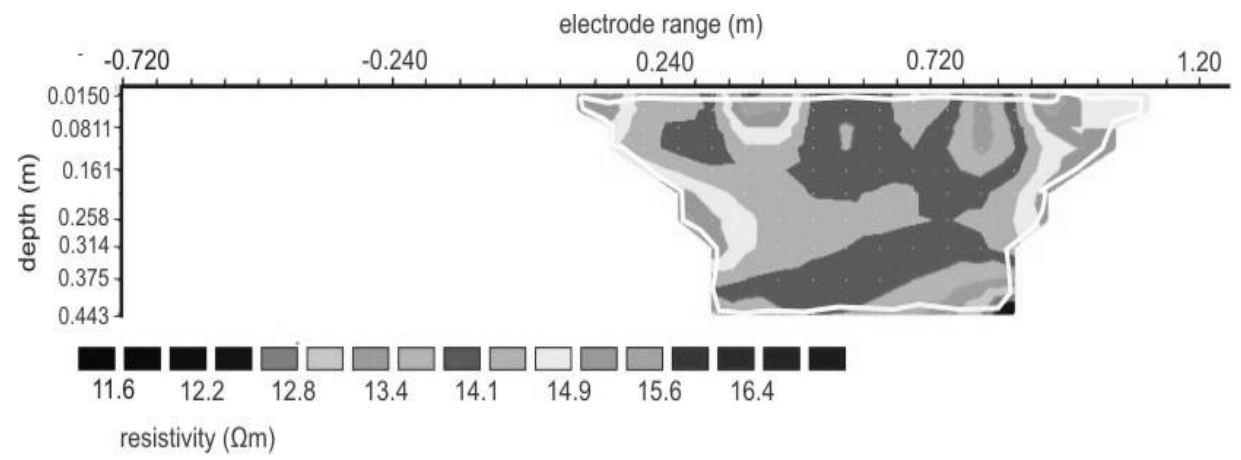

Figure 9. The resistivity pseudo section of the soil at saturation

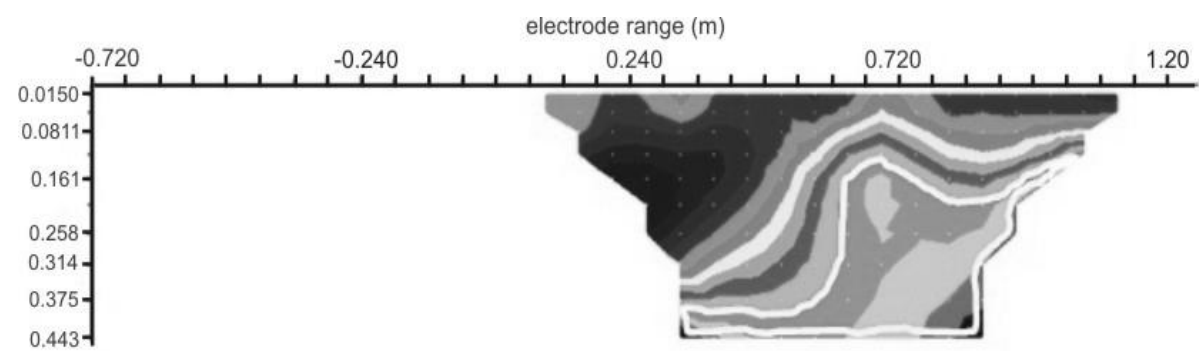

$0.443-$

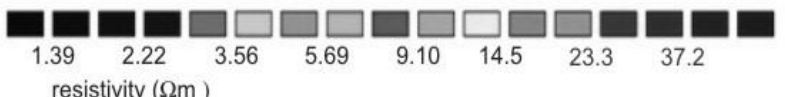

resistivity $(\Omega \mathrm{m})$

Figure 10 . The resistivity psedudo section of the soil that intruded by seawater 
TABLE 1.

The Resistivity Values of Some GeOlogical Materials [8]

\begin{tabular}{cc}
\hline Materials & Resistivity $(\Omega m)$ \\
\hline Air (in earth) & $\sim$ \\
Quartz & $4 \times 10^{10}$ \\
Calcite & $5.5 \times 10^{13}$ \\
Rock salt & $10^{2} \mathrm{~s} / \mathrm{d} 10^{5}$ \\
Granite & $5 \times 10^{3} \mathrm{~s} / \mathrm{d} 5 \times 10^{7}$ \\
Limestone & $60 \mathrm{~s} / \mathrm{d} 3 \times 10^{3}$ \\
Sandstone & $1 \mathrm{~s} / \mathrm{d} 10^{3}$ \\
Stone flakes & $20 \mathrm{~s} / \mathrm{d} 2 \times 10^{3}$ \\
Clay and soil & $1 \mathrm{~s} / \mathrm{d} 10^{4}$ \\
Distilled water & $2 \times 10^{5}$ \\
Water surface & $30 \mathrm{~s} / \mathrm{d} 3 \times 10^{3}$ \\
Groundwater & $40 \mathrm{~s} / \mathrm{d} 6 \times 10^{2}$ \\
Seawater & 0.21 \\
\hline
\end{tabular}

TABLE 2.

SOIL RESISTIVITY AFTER WATERING FRESHWATER

\begin{tabular}{ccc}
\hline $\begin{array}{c}\text { Dry soil resistivity before } \\
\text { watering }(\Omega \mathrm{m})\end{array}$ & $\begin{array}{c}\text { Cummulative volume of water } \\
\text { (liters) }\end{array}$ & $\begin{array}{c}\text { Soil resistivity after watering } \\
(\Omega \mathrm{m})\end{array}$ \\
\hline & 150 & $54.55-78.08$ \\
$79.40-93.87$ & 300 & $31.6-37.8$ \\
& 427.5 & $13.4-15.25$ \\
\hline
\end{tabular}

\section{REFERENCES}

[1] Fahrudin, "Penentuan zona campuran akibat intrusi air laut dengan pendekatan kimia," Jurnal Teknik, vol. 17, no. 2, pp.117-125, 2006.

[2] T. Zubaidah dan B. Kanata, "Pemodelan fisika aplikasi metode geolistrik konfigurasi schlumberger untuk investigasi keberadaan air tanah," Teknologi Elektro, vol. 7, no. 1, pp. 20-24, 2008.

[3] A. M. Law and W. D. Kelton, Simulation Modeling and Analysis $3^{\text {rd }}$, Mc Graw Hill Pers, USA, 1991.

[4] M. Juandi, "Aplikasi metode geolistrik dalam menganalisis distribusi limbah kelapa sawit," Jurnal Natur Indonesia, vol. 5, no. 2, pp. 119-123, 2003.

[5] Ngadimin dan G. Handayani, "Aplikasi metode geolistrik untuk alat monitoring rembesan limbah (penelitian model fisik di laboratorium)," JMS, vol. 6, no. 1, pp. 43-53, 2001.
[6] W. K. Kosinki and W. E. Kelly, "Geoelectric soundings for predicting aquifer properties," Journal Groundwater, vol. 19, no. 2, pp. 163-171, 1981 .

[7] Geotomo Software, "Manual software Res2DInv ver. 3.54. Geoelectrical Imaging 2D and 3D, Geotomo Software", Penang, 2004.

[8] W. M. Telford, Applied Geophysics $2^{\text {nd }} e d$, Cambridge University, 1990.

[9] Supriyadi, "Pendugaan kandungan air tanah dan air asin dengan geolistrik”, Majalah Lonawarta, vol. 15, no. 1, pp. 51-67, 1991.

[10] M. H. Loke, "Electrical imaging surueys for environmental and engineering studies, a practical guide to 2-D and 3-D Surueys: Manual of RES2DINV and RES3DINV softwares", 2000.

[11] A. Wahab, Pemetaan distribusi intrusi air laut dengan menggunakan metode geolisrtik, 2008. [Online]. Available : http: //library.um.ac.id/freecontents/index.php/detail/ 